\title{
A Review on Outcome Based Education and Factors That Impact Student Learning Outcomes in Tertiary Education System
}

\author{
Hafiz Muhmmad Asim ${ }^{1}$, Anthony Vaz ${ }^{2}$, Ashfaq Ahmed $^{3}$ \& Samreen Sadiq ${ }^{1}$ \\ ${ }^{1}$ Lahore College of Physical Therapy, Lahore Medical and Dental College, Lahore, Pakistan \\ ${ }^{2}$ School of Transport and Logistics, Malaysia University of Science \& Technology, Kota Damansara, Petaling \\ Jaya, Malaysia \\ ${ }^{3}$ Department of Orthopedics and Spine, Ghurki Trust Teaching Hospital, Lahore, Pakistan \\ Correspondence: Hafiz Muhammad Asim, Lahore College of Physical Therapy, Lahore Medical and Dental \\ College, Lahore, Pakistan. E-mail: hafizasim@gmail.com
}

Received: July 16, 2020

doi:10.5539/ies.v14n2p1
Accepted: September 9, 2020

Online Published: January 25, 2021

URL: https://doi.org/10.5539/ies.v14n2p1

\begin{abstract}
Education opens numerous revenues to register economic expansion all around the world with specific reference to developing nations. Advancement of Pakistan in education indicators has been severely insufficient during the previous decades. Decreased financing along with inefficiency in budget expenditure plus weak management system have crippled the education sector ensuing poor educational outcomes. Outcome-based Education (OBE) has recently gained much attention in Pakistan. OBE is used in education because it clearly focuses and organizes everything in an educational system around what is necessary for all students to be able to do at the end of their learning. OBE proposes an influential and interesting option of transforming and organizing medical education. Therefore, the basic aim of this review is to highlight the tertiary education system of Pakistan and the need to shift from teacher centered to Outcome Based Education system. The review also addresses the major factors that impact student learning outcomes. Data bases were searched including Cochrane and Medline. Search strategy was designed by combining Boolean operators and key terms related to review objectives. Seven studies were included in the paper regarding the effectiveness of Outcome Based Education in different disciplines of education. The findings suggested five important factors from the literature that impact student learning outcomes including, assessment strategies, learning objectives based on level of complexity, student preferred learning styles, English language competency and Employer requirements. However, limitations were recognized in the methodology section and further recommendations were given for future researchers.
\end{abstract}

Keywords: higher Education, outcome based education, student learning outcomes

\section{Introduction}

In the early nineteenth century, investment in human resources had least importance in any nation. Expenditures on education, continuing professional development and related other types of investments were trivial. This trend started changing during current century with the utilization of technology and science for the manufacturing of latest equipment and more advanced ways of production in Britain and later adopted by other countries as well. Nation's growth and prosperity now depends on education, competency, knowledge and efficiency of the citizens. Presently, this century can also be known as Age of Capital in relation to the fact that main determining factor of nation's criteria of standard living is how effectively it utilizes the skills, practical knowledge and competencies (Ozturk, 2008). Education opens different revenues to register economic expansion all around the world with specific reference to developing nations. The global statistics showed that education and economic growth are directly related to each other in a positive direction and have constancy to each other (Rahman, 2013).

Education has the power to open the window of creativity and novelty among Pakistan's over two hundred million human capitals. Therefore, Pakistan has to meet an important task to provide its youth with knowledge, creativeness, vision, critical thinking, and leadership qualities so that they can make right decisions for themselves, their nation and play a responsible part as citizens. For that purpose, crystal clear information of challenges regarding education system is required so that appropriate methods could be devised to address them. Advancement of Pakistan in education indicators has been severely insufficient during the previous decades. The 
country lacks educated and skillful human resource that can take part in the development of country. Decreased financing along with inefficiency in budget expenditure plus weak management system have crippled the education sector ensuing poor educational outcomes (Ali \& Jabeen, 2015).

Government is putting their continuous efforts to perk up both quantity and quality of education by provision of adequate educational facilities. A 10 percent increase in the literacy rate was observed within 6 years in Pakistan, with 45\% rate during 2001 to 2002 and over $55 \%$ from year 2006 to 2007 (Abbas \& Foreman-Peck, 2008). In past, Pakistan failed in attaining the target associated to education as the preferred changes to upgrade the system could not be made in education sector. Currently the intent of government is to meet the Sustainable Development Goals (SGDs) with the chief aim to guarantee comprehensive and equal quality education along with promotion of lifelong learning chances for all through substantial improvements in education (Nazar, Chaudhry, Ali, \& Faheem, 2018).

To ensure stability in economic productivity, variances in the workingmen market need a thorough review together with inspecting prudentially the economic requirements about necessary understanding and working capability. The entire educational system should be modified so as to produce capable and innovative workmen who could effectively contribute towards economic progress. Venturing in the field of education not only amounts to inflate human capital but is also indispensable to manage envious living standards.

Investment in education in terms of incorporation of new educational approaches, novel technologies, modified teaching methodology, defined objectives formulation can stimulate economic prosperity that results in further educational system transformation and then more economic growth (Woo, Kim, \& Lim, 2017). Considering different levels of education, its impact should be different on economic growth. Higher education directs towards higher economic expansion and growth. In Taiwan between the years of 1965 to 2000, it has been seen that an extra one year of education resulted in increase of $0.15 \%$ outcome (Lin, 2004).

In Pakistan the current educational methods focus on inputs. The educational system exposed the students to a part of curriculum over specific time period. At the end of the session, an examination is taken and grades are given to the students despite considering the fact that all students have attained mastery of the content learned. This viewpoint and approach of education system needs to be transformed. Outputs is not merely attaining good results but a clearly focused and organized educational system around what is necessary for all students to be able to do at the end of their learning. Outcome Based Education (OBE) has appeared as a chief direction for educational reform in the United States. Students of current generation do not want to develop only the theoretical basis but also seek an education approach where the focus lies on future employment also (Zakaria \& Yusoff, 2010).

This approach had gradually won a lot of supporters from other nations. In South Africa OBE model was selected and introduced because the stress in curriculum was particularly on factors like problem solving, idea generation, skill acquisitions that aims at developing clear thinking and competent citizens (Botha, 2002). Whereas in Malaysia the transition from conventional teaching approaches to focus on students learning outcomes is eventually gaining importance and a significant feature that cannot be overlooked (Mohayidin, Suandi, Mustapha, \& Konting, 2008).

Outcome-based Education (OBE) has recently gained much attention in Pakistan. OBE is used in education because it clearly focuses and organizes everything in an educational system around what is necessary for all students to be able to do at the end of their learning (Spady, 1994).

Educators have always shown interest in understanding the key factors that affect student learning outcomes and focuses on the delivery of knowledge and skills in a way necessary for their integration into the public and economy. It has now been realized by the world educators that learning is not merely the knowledge delivery. It's about involving cognitive process of knowledge generation, strongly influenced by the cultural, societal and emotional factors. Educational system in Pakistan is still dominated by the traditional teaching process in which defined curriculum is taught to the students using conventional teaching methods (Portnov-Neeman \& Barak, 2013).

Therefore, the basic aim of this review is to highlight the tertiary education system of Pakistan and the need to shift from teacher centered to Outcome Based Education system. The review also addresses the major factors that impact student learning outcomes. Moreover, we aimed to give future directions for further research. As outcome based education is trending in Pakistan and there is intense need to evaluate factors that impact student learning outcomes, the current review provide a comprehensive review of the whole theme. 


\section{Methods}

\subsection{Search Strategy}

Two data bases were searched including Cochrane and Medline. A thorough search was performed to retrieve articles missed through databases as well as unpublished grey literature. Search strategy was designed by combining Boolean operators and key terms related to review objectives. The search terms utilized for Outcome Based Education were "competency based education", "active learning approach", "outcome based assessment". The filters applied were English language and published literature from 2005 till 2020. Those articles were included which were published in peer reviewed journals.

\subsection{Study Selection}

The records were first identified through titles and abstracts from Cochrane library and Medline with an emphasis on topic related to Outcome Based Education in different universities around the world. Screening of records was done and then assessment of full text articles was performed according to the eligibility. Final inclusion of studies was done for qualitative synthesis. The study evaluated Outcome based Education in universities offering Engineering, Social Sciences, Nursing and Accountancy. Different factors were also reviewed that could impact student learning outcomes. Preferred Reporting Items for Systematic Review and Meta-analysis (PRISMA) guidelines were followed for the final inclusion of studies.

\section{Results}

A total of seven studies were included in the paper regarding the effectiveness of Outcome Based Education in different disciplines of education conducted in different parts of the world as shown in Table 1. One study was conducted in Hongkong, 3 studies in Malaysia, 2 studies in Philippines and 1study conducted in Canada. There were different disciplines included in the review. 1 study was conducted in Software Engineering, 1 in Nursing Education, 1 study conducted in Accountancy, 1 study in Veterinary Medicine, 1 in Administrative Science, 1 study conducted in Social Sciences and 1 in Technological Sciences. The earliest study included in the review was conducted in 2008 in Universiti Putra Malaysia. Majority of the studies utilized quantitative designs with Cross-Sectional study type. The sample size almost ranges from almost 50 to more than 700 students. Data from the faculty was also collected in the studies to provide a detailed understanding of the effectiveness of OBE from both students and teachers perspective. The nature of each included study is summarized in the Appendix section. Major factors that could impact Student Learning outcomes were also analyzed and categorized into five important factors in a developing nation like Pakistan. The themes were: learning objectives on the basis of Bloom's Taxonomy, assessment methods, English language competency, learning styles and employer graduate requirements. These themes were discussed individually in the sections below.

Table 1. Matrix of 7 reviewed articles

\begin{tabular}{|c|c|c|c|c|c|}
\hline Authors & Location & Purpose & $\begin{array}{c}\text { Study } \\
\text { Design }\end{array}$ & Measurements & Conclusion \\
\hline $\begin{array}{l}\text { (Hong-Ning } \\
\text { Dai, } \quad \text { Wei } \\
\text { Weiet, Hao } \\
\text { Wang, } \quad \& \\
\text { Tak-Lam } \\
\text { Wong, 2017) } \\
\end{array}$ & $\begin{array}{l}\text { Hong } \\
\text { Kong }\end{array}$ & $\begin{array}{l}\text { To evaluate the impact } \\
\text { of Outcome Based } \\
\text { Assessment on } \\
\text { learning method of } \\
\text { student and faculty } \\
\text { practices }\end{array}$ & Quantitative & $\begin{array}{l}\text { Scoring of grades among } \\
\text { students in both control } \\
\text { (without OBE) and } \\
\text { experimental group (with } \\
\text { OBE) }\end{array}$ & $\begin{array}{l}\text { Outcome Based Education } \\
\text { significantly improved the } \\
\text { learning outcomes of students and } \\
\text { quality of teaching practices of } \\
\text { faculty. }\end{array}$ \\
\hline $\begin{array}{l}\text { (Kaliannan \& } \\
\text { Chandran, } \\
\text { 2012) }\end{array}$ & Malaysia & $\begin{array}{l}\text { To determine the level } \\
\text { of empowerment of } \\
\text { students after } \\
\begin{array}{l}\text { implementation of } \\
\text { Outcome Based } \\
\text { Education }\end{array}\end{array}$ & Quantitative & Two sets of Questionnaire & $\begin{array}{l}\text { The overall implementation of the } \\
\text { OBE method at the faculty has } \\
\text { achieved its desired objectives. } \\
\text { Students are able to gauge their } \\
\text { own understanding and ability for } \\
\text { each of the subjects that they take. }\end{array}$ \\
\hline
\end{tabular}




\begin{tabular}{|c|c|c|c|c|c|}
\hline $\begin{array}{l}\text { (Imelda 1. An, } \\
\text { 2014) }\end{array}$ & Philippine & $\begin{array}{l}\text { To assess the } \\
\text { effectiveness of OBE } \\
\text { among university } \\
\text { students related to } \\
\text { change in their } \\
\text { behavior and } \\
\text { performance after } \\
\text { implementation of } \\
\text { OBE strategy }\end{array}$ & $\begin{array}{l}\text { Descriptive } \\
\text { study }\end{array}$ & $\begin{array}{l}\text { Questionnaire. It consists } \\
\text { of three parts. First part } \\
\text { examines the demographic } \\
\text { features, second part } \\
\text { evaluates the effectiveness } \\
\text { of OBE and third part } \\
\text { evaluates the implications } \\
\text { of OBE in curriculum } \\
\text { designing. }\end{array}$ & $\begin{array}{l}\text { From the findings generated, the } \\
\text { OBE Instruction can be accepted } \\
\text { and learned for new educational } \\
\text { system regardless of age and } \\
\text { gender. It caters to any } \\
\text { accountancy student who is } \\
\text { willing to adapt to the new } \\
\text { curriculum. }\end{array}$ \\
\hline $\begin{array}{l}\text { (Mohayidin } \\
\text { et.al., 2008) }\end{array}$ & Malaysia & $\begin{array}{l}\text { To evaluate the } \\
\text { effectiveness of OBE } \\
\text { in attainment of } \\
\text { student learning } \\
\text { outcomes. }\end{array}$ & Quantitative & $\begin{array}{l}\text { Instrument. It measures two } \\
\text { major domains: learning } \\
\text { outcomes and teaching. } \\
\text { The scale ranges from } 1 \text { to } \\
10.1 \text { depicts lowest } \\
\text { attainment level of student } \\
\text { outcomes and } 10 \text { represents } \\
\text { highest perceived level of } \\
\text { attainment. }\end{array}$ & $\begin{array}{l}\text { The results showed that the } \\
\text { highest score went to providing } \\
\text { knowledge to students, while the } \\
\text { least achievable learning outcome } \\
\text { was managerial and } \\
\text { entrepreneurial skills. The results } \\
\text { also infer that soft-skills among } \\
\text { students were lacking and this } \\
\text { problem needs to be addressed } \\
\text { quickly and effectively. }\end{array}$ \\
\hline $\begin{array}{l}\text { (Katherine Tan } \\
\text { et. al., 2018) }\end{array}$ & Malaysia & $\begin{array}{l}\text { To synthesize and } \\
\text { summarise the best } \\
\text { evidence that evaluates } \\
\text { the effectiveness of } \\
\text { Outcome based } \\
\text { method on the } \\
\text { competency level of } \\
\text { nursing students. }\end{array}$ & $\begin{array}{l}\text { Systematic } \\
\text { Review }\end{array}$ & Review Methods & $\begin{array}{l}\text { Positive effects on nursing } \\
\text { students competencies were } \\
\text { observed after OBE interventions. } \\
\text { Improvement in knowledge } \\
\text { acquisition, nursing skills and } \\
\text { attitudes were identified as } \\
\text { primary outcome measures. }\end{array}$ \\
\hline $\begin{array}{l}\text { (De Guzman } \\
\text { et. al., 2017) }\end{array}$ & Philippines & $\begin{array}{l}\text { To understand the } \\
\text { detailed concept of } \\
\text { Outcome based } \\
\text { education and its } \\
\text { implementation in } \\
\text { technology }\end{array}$ & $\begin{array}{l}\text { Descriptive } \\
\text { and } \\
\text { Quantitative }\end{array}$ & $\begin{array}{l}\text { Survey Instrument. The } \\
\text { instrument has } 23 \text { key } \\
\text { questions and the score } \\
\text { ranges from } 5 \text { to } 0 \text {. It has } \\
\text { two sections. First section } \\
\text { evaluates the understanding } \\
\text { of OBE and second portion } \\
\text { determines the knowledge } \\
\text { of implementation. }\end{array}$ & $\begin{array}{l}\text { The faculty members reported a } \\
\text { great extent of knowledge of the } \\
\text { OBE mainly the use of different } \\
\text { techniques to assess student } \\
\text { learning, though there is a } \\
\text { moderate extent of knowledge on } \\
\text { curriculum alignment and } \\
\text { mapping and construction of } \\
\text { Program Educational Objectives } \\
\text { (PEOs) of the different Colleges. }\end{array}$ \\
\hline $\begin{array}{l}\text { (Dawson et.al., } \\
\text { 2013) }\end{array}$ & Canada & $\begin{array}{l}\text { To examine the impact } \\
\text { of outcome based } \\
\text { education on student } \\
\text { learning outcomes and } \\
\text { teaching practices of } \\
\text { faculty }\end{array}$ & $\begin{array}{l}\text { Mixed } \\
\text { method } \\
\text { study }\end{array}$ & $\begin{array}{l}\text { Two-phase method } \\
\text { involving a focus interview } \\
\text { group and questionnaire }\end{array}$ & $\begin{array}{l}\text { Faculty members' instructional } \\
\text { practices improved through the } \\
\text { alignment of instruction and } \\
\text { curriculum. This snapshot of the } \\
\text { early stages of implementing a } \\
\text { competency-based program has } \\
\text { been instrumental in refining and } \\
\text { advancing the program. }\end{array}$ \\
\hline
\end{tabular}

\subsection{Review on Outcome Based Education}

OBE proposes an influential and interesting option of transforming and organizing medical education (Dai et al., 2017) and can be applied to other disciplines as well. The notion of accountability proved to one of the reason for swift spread of different types of OBE in countries like Malaysia, United States, Australia, South Africa and many others (Akir, Eng, \& Malie, 2012). This call for accountability and the ever increasing number of physical therapists for example; entering the professional field with lack of skills and techniques has placed an increased focus on curriculum designing and practical assessment in physical therapy educational institutes of Pakistan. Therefore, twenty-first century reorganization demands for a paradigm shift from theoretical material like knowledge and conceptual understanding of curriculum to competencies and skill development which includes 
describing what students are capable to do with what they are learning as the center of education and appraisal. OBE is not merely the educational method of choice but a significant component of education specifically in teaching and learning procedure. It highlights the outcome, where accomplishments of students are computable, verified and could be improved (De Guzman, Edaño, \& Umayan, 2017) .

Some of the early effects and benefits of OBE include formation of more organized, novel and modifiable teaching methods. For example, project learning will be promoted and development of professional attitude and skill will be implemented. Moreover the educational institutes are always attentive and watchful about the quality of graduates produced and introduced in market (Yusoff, Fuaad, Yasin, \& Tawil, 2014).

The Washington Accord is an autonomous agreement between national organizations that grant external accreditation to tertiary educational programs. It allows the graduates to meet the criteria for access into professional engineering practice. The signatories commence a well-defined procedure of episodic peer review to make sure each other's accredited programs are significantly comparable and their outcomes are relatable with the published professional engineer graduate attribute exemplar. Signatories agree to award graduates of each other's accredited programs the similar acknowledgment, rights and privileges as they provide to graduates of their own accredited programs. Through this, the Accord assists mobility of graduates between signatory jurisdictions and deeper understanding and recognition of their engineering education and accreditation systems. At present there are 15 signatories to the Washington Accord that deliver more than seven thousand programs producing graduates that are appreciably related in skills and competencies (Sunyu, 2007).

Pakistan Engineering Council's (PEC) affiliation with Washington Accord opens a window of opportunity for Pakistani degrees to be of the same value as in the developed countries. Currently at Iqra National University Peshawar, they are striving efforts to become the member of Washington Accord. They must be required to employ OBE in comparison to the present practice in the Engineering Degree Awarding Institutes (EDAI) in Pakistan. They proposed a Faculty Course Assessment Report (FCAR) for the purpose of assessment and appraisal of student performance in the undergraduate electrical engineering program whereas directing their early steps toward the Washington Accord accreditation of electrical engineering program (Mahmood, Khan, Khan, \& Kiani, 2015). As opposed to engineering program, the role of OBE and the impact of associated factors on students learning outcome must be evaluated in fields of social sciences.

OBE like other concepts in learning has been described in numerous ways but the core concept remains same that is by evaluating what is required to achieve and accomplish learning outcomes. The thoughts regarding OBE can be found in the early 80's until recently developed models of curriculum designing (Balid, Alrouh, Hussian, \& Abdulwahed, 2012). OBE can be explained as a complete learning teaching method which highlights the students' performance and productivity at the end of learning. The core concept of OBE has been coined by Spady who had made an excellent contribution in laying the theoretical foundation and grounding of OBE (Sekhar, Farook, \& Bouktache, 2008).

Educator centered to student centered approach evaluation in OBE needs a shift in attitude and frame of mind of educators and educational authorities. The shift necessitates a rotation of teaching method from educator-centered to student-centered (Macayan, 2017). Some of the differentiating characteristics between traditional teaching and OBE approach have been shown in Table 2.

Table 2. Teacher centered to active learning approach (Source: Macayan, 2017)

\begin{tabular}{ll}
\hline Traditional learning & OBE Approach \\
\hline What are our teachers' practices? & What our students have learned and capable to display? \\
Teaching (contribution, theoretical material) & Learning (depiction of practical skills, proficiency and outcomes based on knowledge) \\
Teacher-Centered learning & Active learning \\
Teaching and Learning considered as the end & Teaching and Learning as the way to completion \\
Practice decide the outcomes & Outcomes update and modify practice \\
\hline
\end{tabular}

A very simple thought has been promoted within the department of education about organization reforms. It was believed that clear educational standards should be established and accountability of results must be ensured. This latest wave about institution reforms opened the window of opportunity for attainment of cognitive competence (Hatch, 2013). As most of the educators follow the theory of behaviorism, the new concepts of cognitive and constructivism theories have also made progress. Most of the literature on cognitive theory targeted on the fact that how learner learns the concept and apply it in different situations by the use of information and recall mechanism. 
The learning techniques generated from cognitive theory are altogether known as constructivism which is one of the major factors behind curriculum development and assimilation (Vapnik, 2013).

OBE is not a novel concept. OBE has been formulated since several decades and focused on the significance of learning objectives for designing educational experiences (Guskey, 1994). The four basic queries targeted in that, include what educational aims should the organization seek to accomplish, what learning opportunities should be chosen to achieve those aims, how the learning opportunities be managed in a best way for effective teaching and how the efficiency of learning experiences be assessed. After that, the concept was preceded and emphasis was placed on that, given adequate time, every student could learn what only the brightest student could learn (Carroll, 2012). The data then started to accumulate which directed to the conclusion that with correct training and extra time to learn, nearly all students might learn the fundamental concepts of curriculum (Guskey, 2005). Educational researchers started giving attention to the cognitive theory. A key aspect to instructional background was provided by addressing that when instructions relate to the test and the test relates the desired outcome, a state of instructional alignment has reached (Martone \& Sireci, 2009). Cognitive theory then started generating new learning ways known as webbing or constructivism. Current pedagogical advancements in cognitive psychology offer methods to students to become active learners in knowledge acquisition. The dimension of student empowerment has been introduced and emphasized that it can be achieved when learner utilizes his knowledge. The model included organization of learning experiences and the capability to recall and convey knowledge. Thus learner was considered as a cognitive being, one who was enriched with knowledge, has control over intellectual resources; therefore he could respond actively in different situations (Prawat, 1992).

OBE appears to present the subsequent phase by providing a theoretical background for curriculum designing and directing the attention from cramming course content to depicting competence in actual life situations. Conventionally educators have accessed learning on the basis of standardized tests. Contrary OBE describes learning as what learner can perform in terms of their knowledge. OBE curriculum was originated from a set of extensive visionary aims, formulated to allow students to direct their lives effectively after they ended up their educational experience (Barman, Silén, \& Laksov, 2014). OBE is defined as a complete strategy to improve educational systems and thus improving students learning outcomes. The educational system then devise most efficient plans based on research and experiences to enhance all learning features of institute in order to guarantee accomplishment of intended outcomes (Harden, 2007). Spady has redefined the concept of OBE and stated that OBE means directing and managing the institution strategies and teaching efforts towards attainment of well-defined goals that we would like our students to demonstrate after leaving their institute.

\subsection{Factors Identified in the Literature That Impact Student Learning Outcomes}

\subsubsection{Learning Objectives on the Basis of Levels of Complexity}

Blooms taxonomy is characterized as a set of models utilized to categorize the learning objectives on the basis of levels of complexity. The objectives are covered under the domain of cognitive, affective and psychomotor (Huitt, 2004). In traditional education the main emphasis remains at the cognitive domain and is commonly used to organize the learning objectives, assessment methods and strategies. The cognitive domain is considered as the knowledge based domain which is further broken down into six levels from remembering, understanding, applying, analyzing, evaluating and creating. The first level of knowledge constitutes recognizing or recalling facts, terms, concepts without necessarily considering their meanings. Its characteristics may constitute knowledge of specifics, knowledge of methods of dealing with specifics and knowledge of abstractions. The next level of cognitive domain involves comprehension which engages understanding of facts through managing, evaluating, translating, analyzing and stating the key ideas. The level of application includes utilizing acquired knowledge to solve problems in different contextual conditions. Learner should be capable of employing acquired knowledge to resolve issues, identify relationships and how they utilize in new circumstances. Analysis level involves interpreting and splitting the information into parts, analyzing their correlation, making assumptions and synthesizing evidence to support generality. The features of analysis include analysis of elements, analysis of relationship and analysis of organization. After analysis, the level of synthesis includes formulating a structure from various elements. This step focuses on forming a whole from different components. The final level of evaluation in cognitive domain involves depicting and explaining opinions by giving judgments about authenticity of ideas and information.

The Affective domain of Bloom's taxonomy considers simple to complex levels from assessment of receiving phenomena, responding to a phenomena, valuing, organizing, and internalizing values. Receiving is the lowest level in affective domain in which the student passively gives attention. Learning is not possible without this level. It also involves student's memory. In the responding level student get involved in the learning and plays the role of 
active learner. The student then attaches a value to the acquired knowledge in the valuing level. The organizing level allows student to arrange various values and ideas in a composite manner. In this level student starts comparing, forming relations and explaining what has been learned. In the final level of characterizing, the students try to formulate abstract knowledge.

The last domain of Blooms taxonomy is the Psychomotor domain which proceeds from simple to complex levels starting from assessment of perception, set, guided, mechanism, complex overt response, adaption and origination (Bloom, 2013). The perception level is defined as the ability to utilize sensory cues to direct motor activity. It ranges from stimulation through selection of cues to translation. The set level is described as psychological, physical and emotional sets to act. This domain of psychomotor level is closely associated with the responding to situation level of affective domain. Imitation and the trial error based strategy are targeted in the guided response level of psychomotor domain. Habituation of learned responses and proficient movements are achieved in the mechanism level. The skilled performance of motor activity incorporating complex movement patterns is indicated in the complex overt response level. The next level of adaptation is defined as the level in which skills become well developed and movement patterns can be modified to adjust the requirements. The final level of psychomotor domain includes the creation of new movement patterns on the basis of their developed skills organized around a unique theory or concept (Forehand, 2010).

\subsubsection{Assessment Methods}

Assessments can be categorized in a variety of numerous ways and most of them are rational. One helpful classification of assessments is based on its categorization as diagnostic, formative or summative. An assessment method of students related to and prior to their exposure with specific educational intervention is known as diagnostic. The purpose of this kind of assessment is to evaluate the educational needs of students with the main aim of maximizing the learning process. A profile is generated frequently to identify domains of strength and weakness. With the progression towards OBE, importance must be increased of such kinds of assessments. The formative type of assessment involves an assessment of learners during educational process. The objective behind this kind of assessments is twofold. First, they give feedback to learners as well as teachers which are projected to guide learning. Secondly, the method of assessment itself generates learning. Therefore formative assessment is significant component of education. The third type of assessment known as summative assessment is usually conducted at the completion of period of time. This type of assessment is used to evaluate whether the student has learned what has been taught. As a result, these assessments are generally cumulative and identify whether the learner is competent to enter into professional practice (Dent, 2013).

\subsubsection{English Language Competency}

English language is not only the language of United Kingdom or United States in the current situation of globalization. It has been stated that English which is basically a West Germanic language of England is presently the most extensively used language in world. As the sphere of communication is growing day by day, the extent of this language has also increased. At this time, English has achieved the position of world language or we can say that it has attained the heights of global language. As compared to other languages around the world, English has several reasons to enjoy the prominent place of global language. One of the reasons is that this language has reached to far extents than any other in the history of human evolution. Secondly it encompasses many fields like business, academics, computer, engineering, politics, education and entertainment (Shrestha, Awasthi, \& Pahari, 2018).

Therefore, it can be rightly said that the significance of English in modern world is quite large. English is not foreign language only, it is considered as an international language now. Around the globe, almost every country gives vital importance to the study of English. Enhanced skills in English can subsequently lead to not only a better social life but also provide better job chances and opportunities. From education to job interviews and finally leading to the professional world, communication skills in English language have become very vital and being efficient in English means being capable to convey your ideas clearly and efficiently (Pandey \& Pandey, 2014). Here in Pakistan, most of the job interviews are conducted in the English language and interviewers quickly provide positive remarks and give priority to their first impressions. Lack of skills in language, written or spoken can be one of the possible reasons of lesser chances of securing a job. On the other hand, being efficient in international language can give a good impression and increases the chances of getting a job. English is one of the commonly utilized languages in the business world. Most of the jobs interviews are conducted in this language as well as contracts are also written in this language. So, it can be concluded that English is the language of knowledge in the modern world. 


\subsubsection{Learning Styles}

It has been recognized that each individual prefers different styles and strategies for learning. Everyone possesses a combination of different learning styles. However some people identify that they prefer one learning style and utilize it more as compared to other styles. Others may express that they use variety of styles depending on their context. Thus learning style is not fixed or rigid. Using multiple learning styles for the purpose of learning is a comparatively novel approach. This strategy has recently been recognized by the educators. Traditional schooling follows the concept of logical and linguist methods of teaching only. A restricted range of learning strategies has been utilized in traditional method. Still the teaching institutions mostly reply on book based teaching strategy with exhaustive repetitions and pressured exam method for assessment. Finally the result is that the students who use this learning method is considered as bright while others find themselves in list of dumb students. Therefore understanding and recognizing your own learning style, better techniques can be adopted to enhance learning and improves the quality of the learning process (Schmeck, 2013). Learning styles has great influence. The preferred learning style directs the way you learn. It also alters the way of representing experiences, recalling information and the selection of words. It has been shown by the literature that each learning style uses different brain parts. The areas of the brain majorly responsible for each learning style have been identified. For instance, occipital lobes of the brain are responsible for visual sense. The aural learning style is handled by the temporal lobe of the brain. The verbal style is controlled by the Broca's and Wernickei's areas. The cerebral and motor cortex seems responsible for physical type of learning. The logical thinking is driven by the parietal lobes. The frontal, temporal and limbic handle the social type of learning whereas frontal, parietal and limbic activate solitary type of learning (Pashler, McDaniel, Rohrer, \& Bjork, 2008).

\subsubsection{Employer Graduate Requirements}

Regarding the requirements of graduates, many questions have arisen in the minds of employers. The declining standards and level of quality of graduates exiting universities in the name of massification of higher education confused the employers in terms of diversity of courses and qualifications. They express their concerns about graduates completing their studies and leaving universities without vocational skills and competencies for work. Employers show more concern with competencies rather than grades and qualifications when recruiting graduates. The generic skills including communication, team work, and personal qualities were given much importance by the employers (Lowden, Hall, Elliot, \& Lewin, 2011). In a study about skill and recruitment of graduates, it has been found that most of the financial services employers selected graduates on the basis of their generic skills, motivation, flexibility, analytical skills and qualities instead of their core knowledge and specialization (I. Dawson, Jackson, \& Rhodes, 2006). Strong demand from employers regarding generic skills and attributes has also been recognized from the complaints registered by them in sufficient literatures in previous ten years about graduates' lack of readiness for work and job experience (Pittaway \& Thedham, 2005).

\section{Conclusions and Further Research}

The basic aim of this review was to evaluate the effectiveness of Outcome Based Education and important factors that could impact student learning outcome. The review highlighted several factors and the significance of the part of educator in formulating the curriculum in education in such a way as to develop an environment for best possible learning, to provide encouragement to the learners, to gain knowledge from each other and to give feedback throughout the journey. The review focused the fact that OBE approaches does show encouraging effects towards improving competencies. However there is still a debate on the need to conduct more studies with large sample sizes and with rigorous methodology. Moreover a gap has been found in measuring the outcomes like satisfaction level of students and the detailed understanding of the implementation phase, concerns regarding the consumption of time along with the reliability of assessment. The reviewed studies lack the generalizability to all education higher institutions. Thus, directing future researches to consider this threat to internal validity and conduct studies which could be generalized.

One of the significant findings of the literature is the identification of factors especially the issues of English language competency in countries like Pakistan where language proved to be a major barrier. Some the major significance of the current study is that it can be helpful for educational authorities, teachers, consumers, parents as well as the community. On a larger scale it can be useful for education policy developers, curriculum designers and education departments. Educators can identify which direction they have to choose towards reorganizing for improvement. This may serve as a guiding tool for educators towards implementation of OBE. The review can also be useful for monitoring process whether standard educational goals are accomplished and maintained at the end of session. Consumers of education can identify if they can adopt this new method of teaching that involves student learning approach and outcomes are measured at the completion. Parents and the public can assess whether 
outcome based education provide advantage to the learner and can aid them in becoming skilled professional and liable resident of their nation. If parents understand that educators have complete knowledge of OBE and they implemented it effectively, then parents will be sure that their children will cope up with the ever changing situations in world. In this way the study will be helpful for parents also when they will interact with the educators in their learning process. One key feature in the study is about the usefulness for the learners as it will provide them an opportunity to learn effectively keeping in mind their learning ways and capabilities to assist attain projected learning outcome. Since the curriculum is well defined towards student development, performance level would be more competent, organized and proficient.

\section{Acknowledgements}

The authors would like to thank School of Business Malaysia University of Science and Technology. We would also like to thank Prof. Harwinder Singh for his support. Last but not the least we would like to express our deep gratitude to the head of Orthopaedic and Spine Center Professor Amer Aziz for always boosting the morale during different phases of research.

\section{References}

Abbas, Q., \& Foreman-Peck, J. S. (2008). Human capital and economic growth: Pakistan 1960-2003. Lahore Journal of Economics, 13(1), 1-27. https://doi.org/10.35536/lje.2008.v13.i1.a1

Akir, O., Eng, T. H., \& Malie, S. (2012). Teaching and learning enhancement through outcome-based education structure and technology e-learning support. Procedia-Social and Behavioral Sciences, 62, 87-92. https://doi.org/10.1016/j.sbspro.2012.09.015

Ali, H., \& Jabeen, A. (2015). Effects of Education on Economic Growth: Evidence from Pakistan. American Journal of Economics, Finance and Management, 1(6), 579-585.

An, I. L. (2014). Impact of outcome-based education instruction to accountancy students in an Asian University. Asia Pacific Journal of Education, Arts and Sciences, 1(5), 48-52.

Balid, W., Alrouh, I., Hussian, A., \& Abdulwahed, M. (2012). Systems engineering design of engineering education: A case of an embedded systems course. Paper presented at the Proceedings of IEEE International Conference on Teaching, Assessment, and Learning for Engineering (TALE) 2012. https://doi.org/10.1109/TALE.2012.6360407

Barman, L., Silén, C., \& Laksov, K. B. (2014). Outcome based education enacted: teachers' tensions in balancing between student learning and bureaucracy. Advances in Health Sciences Education, 19(5), 629-643. https://doi.org/10.1007/s10459-013-9491-3

Bloom, B. S. (2013). Taxonomy of Educational Objectives.

Botha, R. J. (2002). Outcomes-based education and educational reform in South Africa. International journal of leadership in education, 5(4), 361-371. https://doi.org/10.1080/13603120110118831

Carroll, J. B. (2012). Words, meanings and concepts (I) Readings in Educational Psychology (pp. 33-95). Routledge.

Dai, H.-N., Wei, W., Wang, H., \& Wong, T.-L. (2017). Impact of outcome-based education on software engineering teaching: A case study. Paper presented at the 2017 IEEE 6th International Conference on Teaching, Assessment, and Learning for Engineering (TALE). https://doi.org/10.1109/TALE.2017.8252344

Dawson, I., Jackson, A., \& Rhodes, M. (2006). Graduate skills and recruitment in the city: City of London. https://doi.org/10.1108/00400910810889048

De Guzman, M. F. D., Edaño, D. C., \& Umayan, Z. D. (2017). Understanding the Essence of the Outcomes-Based Education (OBE) and Knowledge of its Implementation in a Technological University in the Philippines. Asia Pacific Journal of Multidisciplinary Research, 5(4).

Dent, J. A. (2013). A Practical Guide for Medical Teachers (4th ed.). Elsevier

Forehand, M. (2010). Bloom's taxonomy. Emerging perspectives on learning, teaching, and technology, 41(4), 47-56.

Guskey, T. R. (1994). Outcome-Based Education and Mastery Learning: Clarifying the Differences.

Guskey, T. R. (2005). Formative Classroom Assessment and Benjamin S. Bloom: Theory, Research, and Implications. Online Submission.

Harden, R. M. (2007). Outcome-based education: the future is today. Medical Teacher, 29(7), 625-629. 
https://doi.org/10.1080/01421590701729930

Hatch, T. (2013). Beneath the surface of accountability: Answerability, responsibility and capacity-building in recent education reforms in Norway. Journal of Educational Change, 14(2), 113-138. https://doi.org/10.1007/s10833-012-9206-1

Huitt, W. (2004). Bloom et al.'s taxonomy of the cognitive domain. Educational psychology interactive, 22.

Kaliannan, M., \& Chandran, S. D. (2012). Empowering students through outcome-based education (OBE). Research in Education, 87(1), 50-63. https://doi.org/10.7227/RIE.87.1.4

Lin, T.-C. (2004). The role of higher education in economic development: an empirical study of Taiwan case. Journal of Asian Economics, 15(2), 355-371. https://doi.org/10.1016/j.asieco.2004.02.006

Lowden, K., Hall, S., Elliot, D., \& Lewin, J. (2011). Employers' perceptions of the employability skills of new graduates. London: Edge Foundation. https://doi.org/10.1080/08832323.2012.697928

Macayan, J. V. (2017). Implementing Outcome-Based Education (OBE) Framework: Implications for Assessment of Students' Performance. Educational Measurement and Evaluation Review (2017), 8(1), 4.

Mahmood, K., Khan, K. M., Khan, K. S., \& Kiani, S. (2015). Implementation of outcome based education in Pakistan: A step towards Washington Accord. Paper presented at the 2015 IEEE 7th international conference on engineering education (ICEED). https://doi.org/10.1177/0020720918790108

Martone, A., \& Sireci, S. G. (2009). Evaluating alignment between curriculum, assessment, and instruction. Review of educational research, 79(4), 1332-1361. https://doi.org/10.3102/0034654309341375

Mohayidin, M. G., Suandi, T., Mustapha, G., \& Konting, M. (2008). Implementation of Outcome-Based Education in Universiti Putra Malaysia: A Focus on Students' Learning Outcomes. International Education Studies, 1(4), 147-160. https://doi.org/10.5539/ies.v1n4p147

Nazar, R., Chaudhry, I. S., Ali, S., \& Faheem, M. (2018). Role Of Quality Education For Sustainable Development Goals (SDGS). PEOPLE: International Journal of Social Sciences, 4(2). https://doi.org/10.20319/pijss.2018.42.486501

Ozturk, I. (2008). The role of education in economic development: a theoretical perspective. Available at SSRN 1137541. https://doi.org/10.2139/ssrn.1137541

Pandey, M., \& Pandey, P. (2014). Better English for better employment opportunities. International journal of multidisciplinary approach and studies, 1(4), 93-100.

Pashler, H., McDaniel, M., Rohrer, D., \& Bjork, R. (2008). Learning styles: Concepts and evidence. $\begin{array}{llll}\text { Psychological science in the public interest, } & 9(3), & 105-119 .\end{array}$ https://doi.org/10.1111/j.1539-6053.2009.01038.x

Pittaway, L., \& Thedham, J. (2005). 'Mind the Gap' Graduate Recruitment in Small Businesses. International Small Business Journal, 23(4), 403-426. https://doi.org/10.1177/0266242605054053

Portnov-Neeman, Y., \& Barak, M. (2013). Exploring Students' Perceptions about Learning in School: An Activity Theory Based Study. Journal of Education and Learning, 2(3), 9-25. https://doi.org/10.5539/jel.v2n3p9

Prawat, R. S. (1992). Teachers' beliefs about teaching and learning: A constructivist perspective. American journal of education, 100(3), 354-395. https://doi.org/10.1086/444021

Rahman, M. S. (2013). Relationship among GDP, per capita GDP, literacy rate and unemployment rate. British Journal of Arts and Social Sciences, 14(2), 169-177.

Schmeck, R. R. (2013). Learning strategies and learning styles. Springer Science \& Business Media.

Sekhar, C. R., Farook, O., \& Bouktache, E. (2008). Continuous improvement process based on outcome based education.

Shrestha, R. N., Awasthi, J. R., \& Pahari, B. R. (2018). Impact of English Language Proficiency on the Job Grabbing Process of Engineers in Nepal and the Other Countries: A Bird's Eye View. Journal of the Institute of Engineering, 14(1), 223-234. https://doi.org/10.3126/jie.v14i1.20088

Spady, W. G. (1994). Outcome-Based Education: Critical Issues and Answers. ERIC.

Sunyu, W. (2007). Washington Accord" and Significance for Reference towards Higher Engineering Education in China. Research in Higher Education of Engineering, 1(003). 
Tan, K., Chong, M. C., Subramaniam, P., \& Wong, L. P. (2018). The effectiveness of outcome based education on the competencies of nursing students: A systematic review. Nurse education today, 64, 180-189. https://doi.org/10.1016/j.nedt.2017.12.030

Vapnik, V. (2013). The nature of statistical learning theory. Springer science \& business media.

Woo, Y., Kim, E., \& Lim, J. (2017). The impact of education and R\&D investment on regional economic growth. Sustainability, 9(5), 676. https://doi.org/10.3390/su9050676

Yusoff, Y. M., Fuaad, N. F. A., Yasin, R. B. M., \& Tawil, N. M. (2014). Achievement of program outcomes in outcome based education implementation - a meta analysis. Paper presented at the Proceedings of the 2014 international conference on industrial engineering and operational management, Bali, Indonesia. https://doi.org/10.6007/IJARBSS/v7-i6/3352

Zakaria, S., \& Yusoff, W. W. (2010). Outcome-based education in a private HIL: perceptions of students. Advances in Management, 3, 31.

\section{Copyrights}

Copyright for this article is retained by the author(s), with first publication rights granted to the journal.

This is an open-access article distributed under the terms and conditions of the Creative Commons Attribution license (http://creativecommons.org/licenses/by/4.0/). 